\title{
Solar Power and Wind Power Management System using Power Line Communication using PSO
}

\author{
S. P. Vijaya Ragavan, V. Vijayalakshmi, M. Krishna kumar
}

\begin{abstract}
This enterprise proposes Particle swarm upgrade based TCSC Compensator in solar primarily based breeze mixture station for Reactive electricity the board and brief adequacy exam. It also hopes to choose the placing parameters of TCSC (Thyristor controlled series Compensator) controller using Particle Swarm Optimization (PSO). The self sufficient cream structure has been reproduced under distinct stacking situations for which a alternate paintings display has been considered. affects due to variable weight, Wind manipulate data and solar fueled insolation have been focused and the distinct direct of the shape has been concentrated inside the midst of normal and accuse situation. era effects related to Reactive strength repayment and voltage sufficiency have been improvised with PSO. [19],[20],[21]
\end{abstract}

Keywords : solar,PSO,Communication

\section{INTRODUCTION}

The passion of Alternating electricity has been increasing an aftereffect of the nonattendance of traditional centrality resources. accelerated energy requests with the aid of virtue of Industrialization and masses rise has placed a heap on wellsprings of age. past due days Renewable essentialness sources are in first-rate power, since it's far circumstance pleasant and less chaotic. distinctive spots because of their faraway region and non-receptiveness of fashionable centrality resources face criticalness crunch and opt for elective importance a while. possible power sources are the principal energies which may be made open at remote places and can be given to the far flung global. practical power resources like breeze, solar arranged essentialness segment are plenitude open within the nature, anyways the simple difficulty getting used of feasible power source is that those are sporadic in nature. Thusly Researchers have gone for setting no brief of what one down to earth energy resources to make a crossbreed framework so one can face up to any exigency which could creates in angle on absence of any power supply at something factor. [14],[ 16], [18]

Thyristor controlled series Capacitor (TCSC) is one of the blueprints facts contraptions and is used to govern stream in transmission lines and assistants in [13], [15] , [17]

Revised Manuscript Received on August 22, 2019

Dr.S.P.Vijayaragavan,Associate Professor,Department of EEE,Bharath Institute of Higher education and Research, Tamilnadu, India

Dr.V.Jayalakshmi ,Associate Professor, Department of EEE, Bharath Institute of Higher education and Research, Tamilnadu, India

M.Krishna Kumar,Assistant Professor, Department of EEE, Bharath Institute of Higher education and Research, Tamilnadu, India

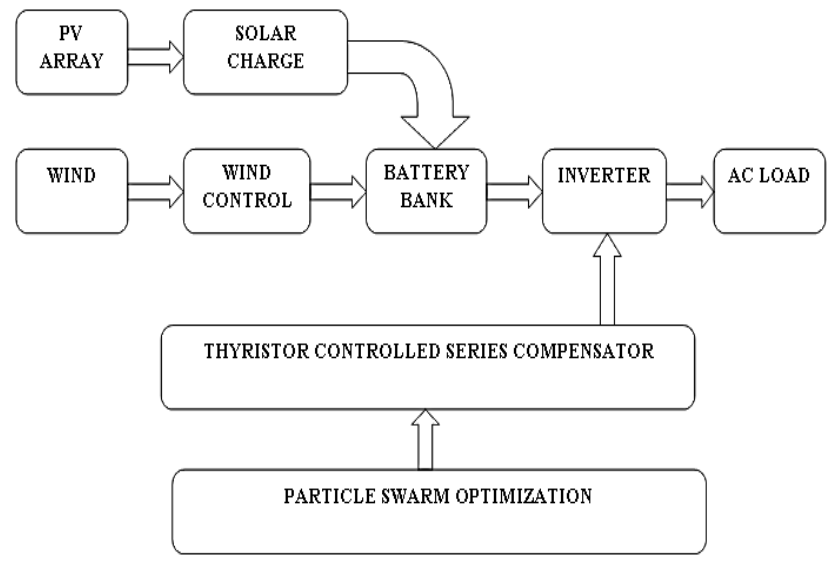

Fig.1.Block Diagram representation of Hybrid wind and solar plant proposed system

\section{DESIGN AND IMPLEMENTATION OF PROPOSED SYSTEM}

Hybrid frameworks comprise of blend of PV modules and a corresponding technique for power age, for example, a diesel, gas or enhancing adequacy and responsive energy pay. TCSC is utilized to redesign control framework heartiness by converting the reactance of transmission line. TCSC needs some greater gainful facts signals than special facts contraptions. Particle Swarm Optimization (PSO) is the control estimation for the buying and selling beat over TCSC required for responsive energy pay. wind generator. With a specific end goal to streamline the distinctive strategies for power age, half breed frameworks regularly require more advanced controls than remain solitary or lattice associated PV frameworks. Wind Turbine demonstrates is for the most part an Induction engine which is favoured in view of its vigorous attributes. The measure of receptive power required by Induction generator is met by FACTS gadget. There is dependably vulnerabilities about breeze information and load input. In this manner settled capacitors are not satisfactory in repaying receptive capacity to the cross breed control framework. ThyristorControlled Series Compensator (TCSC), an arrangement controlled gadget under FACTS family has been ended up being extremely powerful and viable.Particle swarm optimization(PSO) is a populace based stochastic advancement procedure. PSO imparts numerous likenesses to developmental calculation procedures. The PSO can address problems of mixed

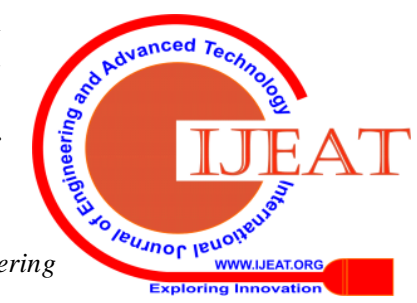


programming, where some components are restricted to be integer-valued.

\section{PARTICLES WARM OPTIMIZATION}

Molecule swarm advancement (PSO) is a masses based stochastic streamlining framework. PSO shares various comparable qualities with transformative figuring techniques. The structure is instated with a people of sporadic game plans and outputs for optima by reviving ages. Atom Swarm Optimization may sound tangled, anyway it's incredibly an outstandingly clear figuring. Over different accentuations, a social event of variables have their characteristics adjusted closer to the part whose regard is closest to the target at some arbitrary minute. The flowchart is speaks to the Particle swarm streamlining stream which is as appeared in the figure 2



Fig.2. flow chart for Particle swarm optimization

You can apply the Particle swarm improvement to deal with a collection of progression issues that are not fitting for standard streamlining counts, fusing issues in which the objective work is uncontrollable, non-differential, stochastic, or exceedingly nonlinear. The Particle swarm improvement can address issues of mixed entire number programming, where a couple of fragments are bound to be entire number regarded.

\section{ThyristorControlled SERIES COMPENSATOR}

Thyristor-Controlled Series Compensation (TCSC) is used in power structures to dynamically the officials the reactance of a transmission line to supply superior to anything normal weight pay. The upsides of TCSC are found in its ability to manage the amount of compensation of a conductor, and in its ability to control in different modes. These characteristics are horribly intriguing since hundreds are relentlessly dynamical and can't generally be foreseen. [8],[10],[12]

TCSC styles work inside unclear strategies from mounted Series Compensation; in any case give variable organization of the reactance devoured by the capacitor contraption.

\section{FACTS}

An adaptable exchanging flow transmission framework (FACTS) is a system made out of static equipment used for the AC transmission of electrical essentialness. It is planned to improve controllability and addition control trade limit of the framework. It is regularly a power contraptions based system. As demonstrated by Siemens "Realities Increase the relentless nature of AC systems and reduce control transport costs. They upgrade transmission quality and adequacy of power transmission by giving inductive or open ability to the cross section. This system is used to upgrade the power factor. At whatever point an inductive weight is related with the transmission line, control factor slacks because of loosen load current. To change, a shunt capacitor is related which draws current driving the source voltage. The net outcome is overhaul in power factor. [7], [9],[11]

Power gear has given, as a front line culture, and a great deal of better approaches to manage make things, give favorable circumstances, and use imperativeness.From an utility inventory structure point of view, these converter-based systems can incite operational and future issues for other equipment, possibly not had or worked by a close social gathering. It was from this focal prospect. Everything considered, identical contraptions and structures that make control quality issues can be used to oversee compel quality issues. [2 ],[ 4],[6]

To make transmission systems work inside wanted voltage breaking points and techniques for making up or removing responsive power is called receptive power control. The AC systems and the gadgets associated with them make related time-fluctuating electrical fields identified with the connected voltage and just as attractive fields reliant on the flow stream and they develop these fields store vitality that is discharged when they breakdown". [1],[3],[5]

Aside from the vitality dissemination in resistive parts, all vitality coupling gadgets (e.g: engines and generators) work dependent on their ability to store and discharge vitality. While the real methods for control of responsive power and voltage is by means of the excitation frameworks of synchronous generators and gadgets might be conveyed in a transmission system to keep up a decent voltage profile in the framework. The shunt associated gadgets like shunt capacitors or inductors or synchronous inductors might be settled or exchanged (utilizing circuit breaker).The Vernier or smooth control of receptive power is additionally conceivable by fluctuating viable susceptance qualities by utilization of intensity electronic gadgets Precedent: Static VarComponsator(SVC)" and a Thyristor Controlled Reactor (TCR).

\section{SOLAR PV SYSTEM}

A photovoltaic system, generally called a Solar PV structure, is an essentialness system that is proposed to change the imperativeness from the sun into power by strategies for photovoltaics, generally called sun fueled sheets. This structure is ensured, reliable, low-backing, and gives proficient power imperativeness without on area pollution or surges. Therefore, by presenting a photovoltaic system, you add to a greener circumstance, and, additionally, you will be an 
owner of a logically sensible home.

Sunlight based photovoltaic frameworks fall into two principle classes: lattice associated and off-matrix frameworks. The lattice is the neighborhood electric utility's framework that provisions capacity to homes and organizations. With respect to the off-lattice frameworks, they are introduced in remote areas where no utility matrix is accessible.

Photovoltaic frameworks are proficient, and introducing them accompanies the accompanying advantages:

1. The sun powered vitality they produce is economical. This is on the grounds that the sun is an inexhaustible asset and can't be over-devoured. Thus, it is a copious and regular source.

2. Sun powered vitality can be created anyplace. In this way, despite the fact that nations closer to the Equator have more prominent potential for creating it, it isn't accessible just to them. It tends to be created anyplace, even on overcast days. Subsequently its accessibility makes it truly profitable and valuable.

Sun based vitality is free. Despite the fact that the establishment costs are high, you won't be charged for the power that the photovoltaic framework will give you later on. Subsequently, sunlight based power is a free power asset.

4. Utilizing sun oriented vitality will lessen your power charges over the long haul. At times, you can likewise create salary by offering your surplus vitality back to your vitality supplier.

5. Having a photovoltaic framework introduced in your home will expand your freedom and the estimation of your home. Subsequently, you won't be subject to nonrenewable vitality assets that you utilized previously.

6. The more homes that utilization sun based vitality, the more employments will be made in the sustainable power source assets. Thus, you will add to a more extensive activity showcase.

Notwithstanding creating power, sun based vitality can be utilized to warm water or to give warmth to homes and organizations. In this manner, sun oriented warm and sunlight based water warming can be fascinating to take a gander at, on the off chance that you need to incorporate sun based vitality all around your home. Additionally, utilizing the freshest advances, for example, thermodynamic boards, water can be warmed by basically misusing the temperature of the surrounding air. Sun based inverters are the third segment of the photovoltaic framework and their motivation is to change over the immediate flow power created by the sun oriented modules into rotating flow power, which is utilized to give control in our homes, just as, the nearby transmission.

Henceforth, this component of the photovoltaic framework enables you to get the power that you use to make your home machines work. Normally, one inverter for all modules is more cost-productive and less demanding to chill off and administration if essential. In a similar vein, it is additionally extensively simpler to supplant these sunlight based PV inverters than it is to supplant miniaturized scale inverters. In any case, microinverters can be progressively favorable if a portion of the modules are secured by shade since they will work autonomously from the modules that are as yet presented to daylight.

Aside from these two essential kinds of inverters, a propelled 'keen inverter' was created, which takes into account two-routes correspondence between the sun powered inverter and the electrical utility. Along these lines a harmony among free market activity can be accomplished, which results in cost decrease, guarantee matrix strength and diminishing the probability of intensity power outage. To most likely measure the amount you are utilizing and the amount you have sustained the utility framework, an utility meter (additionally called net-meter) is associated with the photovoltaic framework.

\section{E.WIND POWER GENERATION SYSTEM}

Wind manipulate is using wind movement via wind generators to provide the mechanical capability to show electric powered generators. Wind manage, as a choice in preference to expending non-sustainable strength assets, is copious, boundless, extensively rotated, smooth, makes no gasoline transmissions within the midst of movement, eats up no water, and uses little land. The net ramifications for nature are some distance much less perilous than the ones of oil subordinate assets.

Winds farms incorporate various man or woman breeze mills, which are related with the electrical power transmission mastermind. seaside the front breeze is a practical wellspring of electric strength, focused with or in numerous spots greater low cost than coal or gas plant life. in the direction of the sea wind is steadier and extra grounded than aground and offshore houses have much less unique visualization, yet development and bolster prices are altogether higher. minimum seaside breeze residences can support some essentialness into the device or provide electric powered ability to isolates off-community zones.

Wind manage gives variable electricity, which is outstandingly reliable from yr to 12 months besides has enormous assortment over shorter time scales. it's miles as such used diagnosed with other electric power sources to provide a dependable stockpile. as the degree of wind manage in an area extends, a need to overhaul the structure and a delivered restrict right down to abrogate standard age can occur.power-the board strategies, for example, having excess breaking factor, geologically exceeded on turbines, dispatchable resources, best hydroelectric electricity, conveying and getting ability to neighboring locales, imperativeness collecting, or lessening interest whilst wind creation is low, can all around destruction these issues.

Weatherguaging awards the electrical-manipulate framework to be installation for the foreseen assortments in progress that arise. A breeze farm is a get-together of wind generators in a comparative territory used for making of electrical power. An large breeze farm may additionally include a couple of hundred individual breeze turbines surpassed on over a comprehensive district, but the land between the turbines may be used for agrarian or diverse purposes. for instance, Gansu Wind Farm, the best breeze farm in the world, has multiple thousand mills. A breeze farm may additionally in like way be observed toward the sea.

\section{BOOST CONVERTER}

a lift converter (journey up converter) is a DC-to-DC manipulate converter that

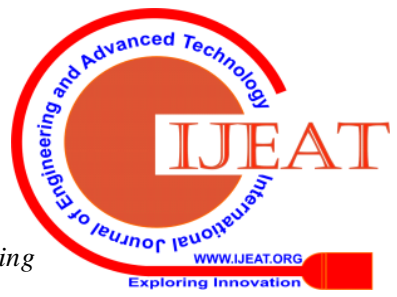


means up voltage (while wandering down present day) from its records (supply) to its yield (load). it is a class of traded mode manipulate supply (SMPS) containing no below semiconductors (a diode and a transistor) and no brief of what one essentialness amassing phase: a capacitor, inductor, or the 2 in mix. to diminish voltage swell, channels made from capacitors (now and again in blend with inductors) are usually delivered to one of these converter's yield (load-facet channel) and facts (supply-side channel). strength for the elevate converter can rise out of any becoming DC sources, as an instance, batteries, solar fueled sheets, rectifiers and DC turbines. A method that changes one DC voltage to an different DC voltage is called DC to DC trade. a boost converter is a DC to DC converter with a yield voltage more sizeable than the source voltage. a boost converter is a part of the time rung a phase converter because it "adventures up" the supply voltage. seeing that strength need to be checked, the yield modern is decrease than the supply present day. Battery manipulate systems generally stack cells in plan to gain better voltage. Regardless, sufficient stacking of cells is ridiculous in numerous high voltage programs in view of nonappearance of room. elevate converters can increase the voltage and diminishing the quantity of cells. two battery-controlled programs that usage help converters are used in $1 / 2$ and half electric cars (HEV) and lighting fixtures systems. the key wellknown that drives the raise converter is the penchant of an inductor to contradict changes in present day by using making and demolishing an appealing area. In a boost converter, the yield voltage is usually higher than the records voltage.

(a) while the transfer is closed, cutting-edge travels thru the inductor clockwise way and the inductor shops a few imperativeness by using making an appealing subject. Furthest factor of the left $50 \%$ of the inductor is certain.

(b) while the transfer is opened, present day will be dwindled as the impedance is better. The appealing discipline as of overdue caused will to be annihilated to preserve up the present day toward the load. alongside these traces the furthest point may be convoluted (infers left $50 \%$ of inductor will be terrible now). along these may be in route of action making a better voltage fee the capacitor via the diode $\mathrm{D}$.

\section{INVERTER}

A electricity inverter, or inverter, is an electronic contraption or device that modifications direct present day (DC) to turning modern (AC).The enter voltage, yield voltage and repeat, and for the most element manipulate coping with rely upon the association of the unique device or gadget. The inverter doesn't convey any power; the strength is given by the DC source. A power inverter can be completely digital or can be a blend of mechanical outcomes, (as an instance, a rotating contraption) and electronic device. Static inverters don't use moving parts within the alternate machine. gadget that plays out the alternative restriction, changing over AC to DC, is called a rectifier. A normal energy inverter tool or circuit calls for a for the most component enduring DC manipulate supply fit for giving enough current to the proposed electricity solicitations of the shape.

The statistics voltage relies upon upon the shape and purpose behind the inverter. factors of reference include: a) $12 \mathrm{~V} \mathrm{DC}$, for greater diminutive consumer and enterprise inverters that usually maintain going for walks from a battery-fueled $12 \mathrm{~V}$ lead unfavorable battery or automobile electrical outlet.

b) 24, 36 and forty eight V DC, that are normal benchmarks for home imperativeness structures.

c) 200 to $400 \mathrm{~V} \mathrm{DC}$, while manipulate is from photovoltaic solar arranged sheets.

d) 300 to $450 \mathrm{~V} \mathrm{DC}$, whilst control is from electric powered automobile battery packs in vehicle-to-prepare systems.

infinite volts, where the inverter is a chunk of a excessive-voltage direct present day power transmission structure. A electricity inverter device which makes a numerous motion sinusoidal AC waveform is suggested as a sine wave inverter. To even greater in reality understand the inverters with yields of substantially less bending than the changed sine wave (three section) inverter systems, the makers generally use the articulation unadulterated sine wave inverter. For all intents and functions all client grade inverters which can be sold as an "unadulterated sine wave inverter" don't make a clean sine wave yield at all lone a less choppy yield than the rectangular wave (two phase) and changed sine wave (three section) inverters. Regardless, this isn't always essential for most system as they deal with the yield excellent.

in which control inverter gadgets alternative for wellknown line manipulate, a sine wave yield is appealing in light of the way that numerous electrical things are labored to work nice with a sine wave AC control supply. the standard electric powered software gives a sine wave, mostly with minor defects but at this factor and in a while with colossal bowing.

Sine wave inverters with numerous methods within the wave yield are more thoughts boggling and have through and via greater distinguished cost than a changed sine wave, with simplest 3 stages, or square wave (one phase) forms of a comparative strength handling. switch-mode control supply (SMPS) gadgets, as an example, computers or DVD players, chip away at exceptional balanced sine wave manipulate. Cooling motors clearly chipped away at non-sinusoidal energy might also make extra warmth, may also have differing speed-torque traits, or can also carry more fit for being heard fuss than while running on sinusoidal energy.

There are a extensive scope of electricity circuit topologies and manipulate strategies utilized in inverter plans. various arrangement methodologies address numerous problems that can be basically basic depending upon how the inverter is intended to be used.

\section{GRID INTEGRATION}

A network combination ponder is an investigative structure used to assess a power framework with high entrance dimensions of variable renewable energy (RE). By and large, network incorporation think about: Simulates the activity of the power framework under various variable RE situations; Identifies unwavering quality requirements; and Evaluates the 
expense of activities to lighten those limitations.

The variable RE situations in a matrix reconciliation ponder set up where, how much, and over what time allotment to fabricate age and transmission limit, in a perfect world catching the spatial assorted variety advantages of wind and sun oriented assets. The outcomes help assemble certainty among policymakers, framework administrators, and speculators to push ahead with plans to build the measure of VRE on the network.

To encourage maintainable, low-outflow improvement, numerous nations are building up aspiring sustainable power source focuses for their power supply. Since sun oriented and wind will in general be more factor and questionable than traditional sources, meeting these objectives will include changes to control framework arranging and tasks. Lattice joining is the act of creating proficient approaches to convey variable renewable energy (RE) to the network. Hearty coordination techniques boost the cost-adequacy of fusing variable RE into the power framework while keeping up or expanding framework dependability and unwavering quality. Framework mix traverses an assortment of issues, including:

1. New RE generation

2. New transmission

3. Expanded framework adaptability

4. Anticipating a high RE future

This examination looks at and writes about endeavours related with incorporating dissimilar utility frameworks (e.g., coordinating supervisory control and information obtaining frameworks, blackout the executives frameworks, geographic data frameworks, and circulation the board frameworks), just as incorporating utility detecting, correspondence and control frameworks with dispersed frameworks or resources possessed and constrained by clients or outsiders (e.g., electric vehicles, vitality stockpiling innovations, building control frameworks and disseminated age advancements like housetop sun based).

\section{Simulation OF PROPOSED SYSTEM}

The proposed technique is implemented in MATLAB simulation software. The simulated model is as shown in the figure 3



The proposed system has solar and wind hybridized is as shown in the figure 4 and 5 respectively



Fig.4.Simulation Model of Solar PV power generation 


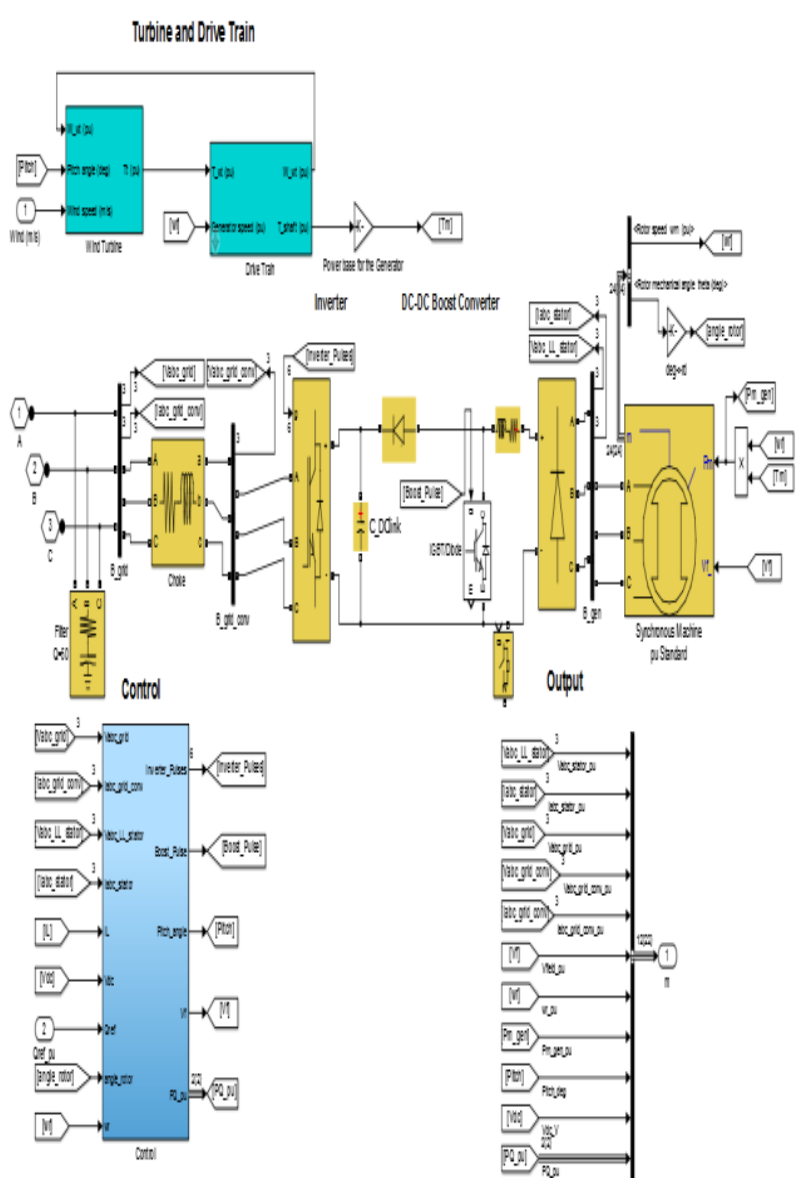

Fig.5.Simulation model Wind power generation system

The TCSC connected to the grid is also simulated in the MATLAB/Simulation software. The simulation model of TCSC is as Shown in the figure 6.

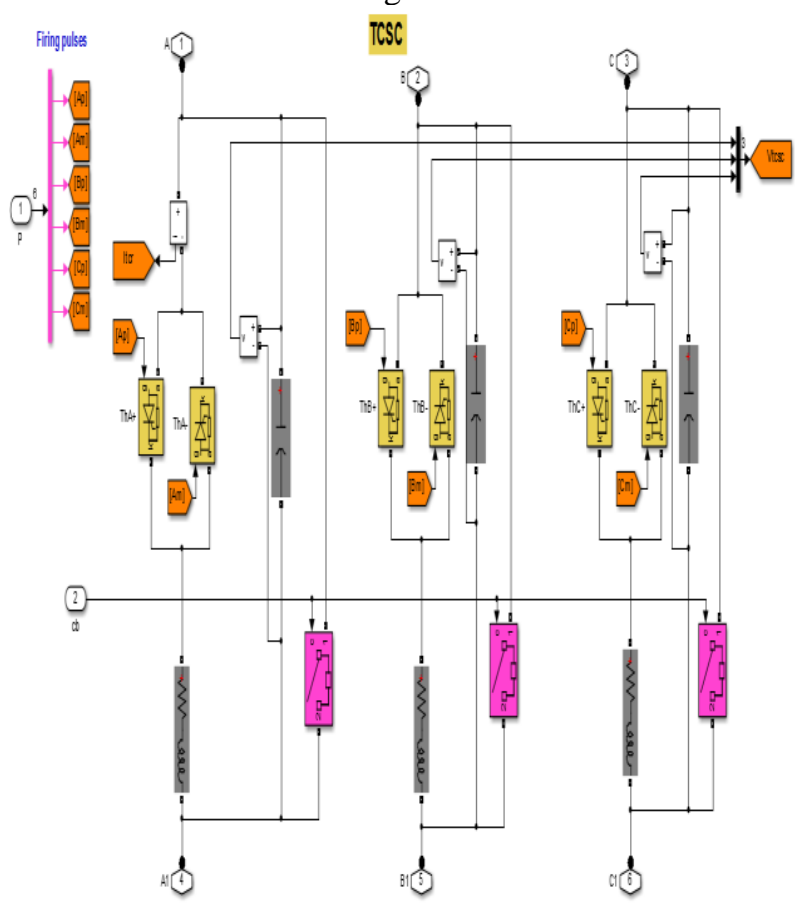

Fig.6.Simulation model of TCSC connection

The proposed TCSC is connected to the grid and the control parameters are used to construct the reactive power compensation. The proposed control system is as shown in the figure 7.

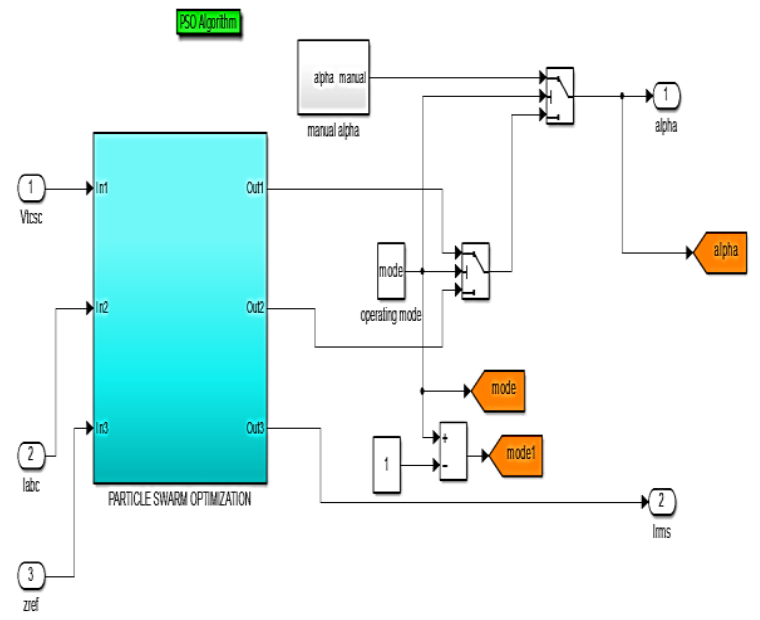

Fig.7. control methodology of proposed system

\section{Simulation OUTPUT AND RESUltS OF PROPOSED SYSTEM}

The above proposed system is simulated with the control topology used. Figure 8 represents the grid power during the TCSC operation from the figure it is clear that the power is restored to $3 \mathrm{kw}$ since the introduction of TCSC

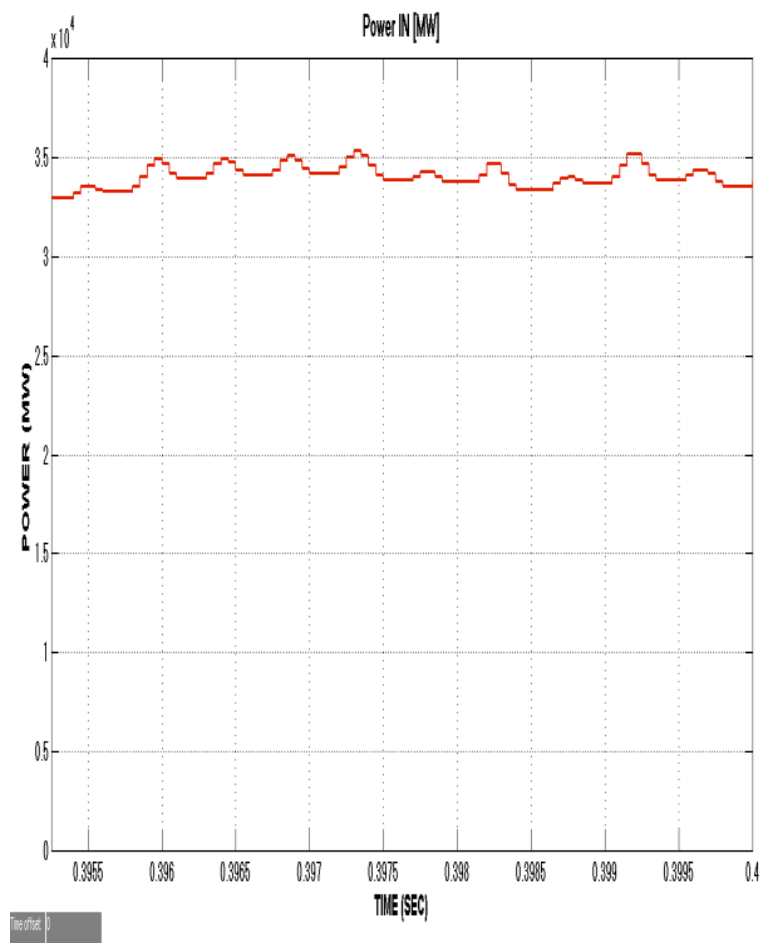

Fig.8.Power output waveform of grid connected hybrid system

The impedance of line and grid is calculated to give control for 
firing angle in TCSC component semiconductor switch when the disturbance occurs the firing angle is given. That's when the actual is different from measured as shown in the figure 9. When there is no reactive power required then the angle comes to 75. That is when there is no difference in actual and measured impedance.

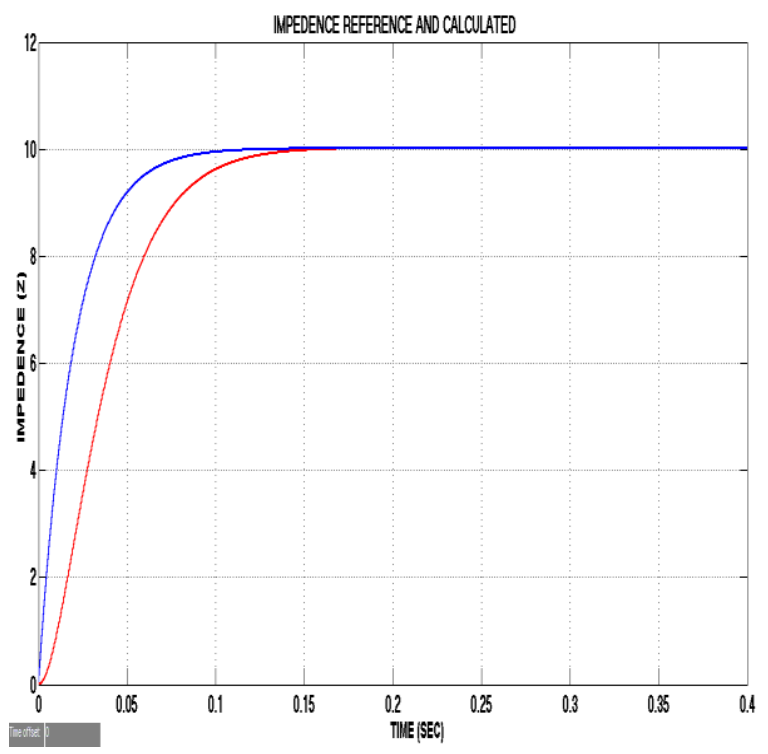

Fig.9. Actual and measured impedance

The firing pulse given to TCSC is called the alpha angle which is as shown in the figure 10 .

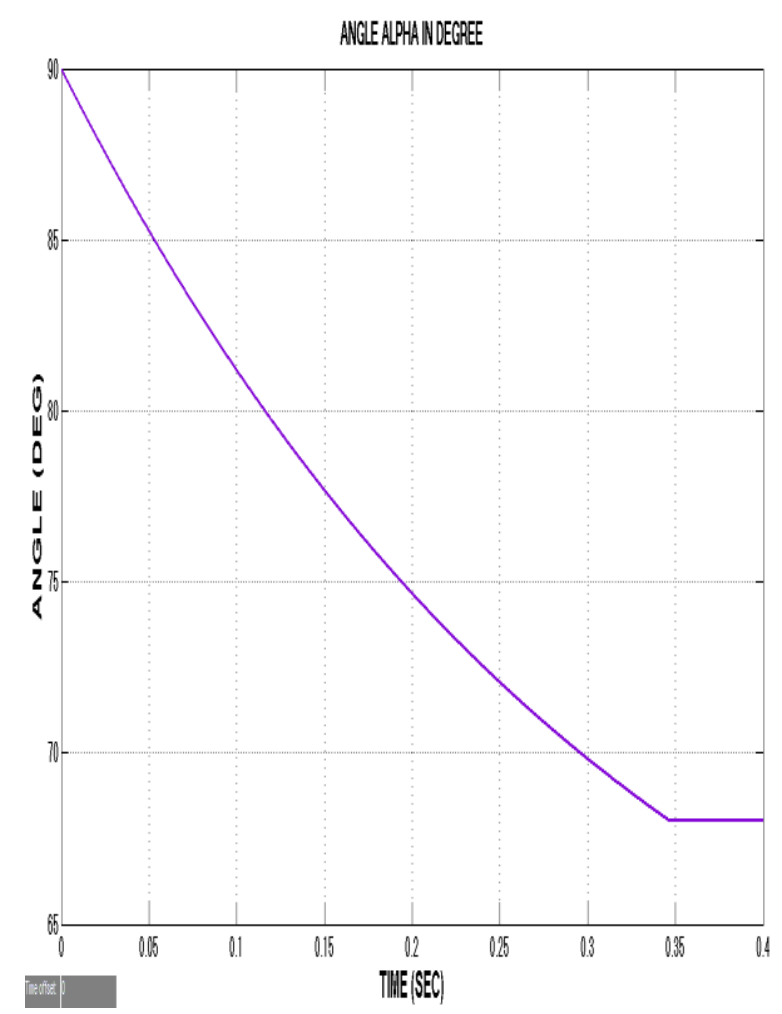

Fig.10.Firing angle Alpha Waveform From the above figure the disturbance where the angel gets reduced and restored to normal value.
Table:1 Quantitative Approach Improvement

\begin{tabular}{|c|c|c|c|c|}
\hline \multirow{2}{*}{$\begin{array}{c}\text { MW power } \\
\text { Generation }\end{array}$} & $\begin{array}{c}\text { PSO } \\
\mathbf{Z} \text { tcsc } \\
\text { compensation time } \\
\text { (sec) }\end{array}$ & $\begin{array}{c}\text { Alpha } \\
\text { Variation in } \\
\text { (deg) }\end{array}$ & $\begin{array}{c}\text { Z tcsc } \\
\text { compensation } \\
\text { time (sec) }\end{array}$ & $\begin{array}{c}\text { Alpha Variation } \\
\text { in (deg) }\end{array}$ \\
\hline $3.5 \mathrm{MW}$ & $0.15 \mathrm{~s}$ & 67.5 & $0.25 \mathrm{~s}$ & 89.9 \\
\hline $4 \mathrm{MW}$ & $0.15 \mathrm{~s}$ & 68 & $0.29 \mathrm{~s}$ & 88 \\
\hline $5 \mathrm{MW}$ & $0.16 \mathrm{~s}$ & 68 & $0.31 \mathrm{~s}$ & 88.2 \\
\hline $5.5 \mathrm{MW}$ & $0.17 \mathrm{~s}$ & 69 & $0.33 \mathrm{~s}$ & 87.5 \\
\hline
\end{tabular}

\section{Conclusion}

The receptive power the board with dynamic steadiness of independent cross breed control framework has been altogether investigated with TCSC controller. The half and half sun powered breeze cross breed framework's reactions as far as settling time, top overshoots and so on amid unfaltering and transient condition are made a decision by the consideration of TCSC compensator. The compensator demonstrates its heartiness with effortlessness in activity and is very versatile in its tendency with various breeze information sources and burden variety. An examination has been drawn between the framework parameters with PSO and GA controller.

It is seen that the time taken for settlement and the voltage dependability of the crossover control framework enhance discernibly with the ascent in intensity of wind vitality framework and the transient security result is enhanced what's more of GA and PSO based TCSC controller.

\section{REFERENCES}

[1] Sharma, R.K., Irusapparajan, G. \& Periyaazhagar, D. 2019 "Three-phase symmetric cascading Z-source seven levels multilevel inverter excited by multi carrier sinusoidal pulse width modulation scheme", International Journal of Innovative Technology and Exploring Engineering, vol. 8, no. 10, pp. 4269-4274.

[2] Velavan, R., Bharanidharan, S. \& Sheeba, B. 2019, "EMF pollution Causes, effects and protection", International Journal of Innovative Technology and Exploring Engineering, vol. 8, no. 9 Special Issue 3, pp. 1166-1168.

[3] Saravana, S., Balaji, S., Arulselvi, S. \& John Paul Praveen, A. 2019 , "Reliable power quality monitoring and protection system", International Journal of Innovative Technology and Exploring Engineering, vol. 8, no. 9 Special Issue 3, pp. 644-645.

[4] Tamil Selvan, S. \& Sundararajan, M. 2019, "Performance Parameters of 3 Value 8t Cntfet Based Sram Cell Design Using H-Spice", International Journal of Recent Technology and Engineering, vol. 8, no. 2 Special issue 5, pp. 22-27.

[5] Jac Fredo, A.R., Abilash, R.S., Femi, R., Mythili, A. \& Kumar, C.S 2019, "Classification of damages in composite images using Zernike moments and support vector machines", Composites Part B: Engineering, vol. 168, pp. 77-86.

[6] Kathiravan, P. \& Govindaraju, C. 2019, "Design and evaluation of ultra gain isolated DC-DC converter for photovoltaic system", International Journal of Engineering and Advanced Technology, vol. 8, no. 5, pp. 2646-2651.

[7] Kripa, N., Vasuki, R. \& Kishore Kanna, R. 2019, "Realtime neural interface controlled au-pair BIMA bot", International Journal of Recent Technology and Engineering, vol. 8, no. 1, pp. 992-994.

[8] Mohanraj, Meenaa Kumari, M., Philomina, S. \& Jasmin, M. 2019, "In-situ humidity measurement of hydrogen fuel cell car using MEMS sensor", International Journal of Recent Technology and Engineering, vol. 8, no. 1, pp. 41-43.

[9] Velmurugan, T. \& Prakash, S. 2019, "Artificial intelligent based distribution automation of swift fault detection isolation and 
power restoration for HT network", International Journal of Innovative Technology and Exploring Engineering, vol. 8, no. 6, pp. 1-6.

[10] Dwarakesh, K. \& Prem Kumar, G. 2019, "Five-level inverter based sequential boost system using fuzzy logic controller", International Journal of Innovative Technology and Exploring Engineering, vol. 8, no. 6, pp. 12-19.

[11] Anne Gifta, A. \& Hemavathi, G. 2019, "Analysis of grid tied solar PV system using ANFIS Algorithm", International Journal of Innovative Technology and Exploring Engineering, vol. 8, no. 6, pp. 312-316.

[12] Jayavel, R., Rangaswamy, T.R. \& Prakash, S. 2019, "Efficient grid management system with renewable and conventional power sources", International Journal of Innovative Technology and Exploring Engineering, vol. 8, no. 6, pp. 287-289.

[13] Hemavathi, G. \& Maheshwaran, S. 2019, "Proportional resonant controlled high gain step-up converter system with improved response", International Journal of Innovative Technology and Exploring Engineering, vol. 8, no. 6, pp. 317-323.

[14] Periyaazhagar, D. \& Irusapparajan, G. 2019, "Design and completion of asymmetric single phase 27 level cascaded mli for various pwm scheme", International Journal of Innovative Technology and Exploring Engineering, vol. 8, no. 6, pp. 792-797.

[15] Mahalakshmi, V. \& Vijayaragavan, S.P. 2019, "PV based power electronic converters for high voltage DC applications", International Journal of Recent Technology and Engineering, vol. 7, no. 6, pp. 670-674.

[16] Irusapparajan, G., Periyaazhagar, D., Prabaharan, N. \& Rini Ann Jerin, A. 2019, "Experimental verification of trinary DC source cascaded h-bridge multilevel inverter using unipolar pulse width modulation", Automatika, vol. 60, no. 1, pp. 19-27.

[17] Sangeetha, G., Sherine, S., Arputharaju, K. \& Prakash, S. 2019, "On Line Monitoring of Higher Rated Alternator using Automated Generator Capability Curve Administer", Proceedings of the IEEE International Conference on \&amp;quot;Recent Trends in Electrical, Control and Communication\&amp;quot;, RTECC 2018, pp. 176.

[18] Bycil, V.J. \& Wiselin, M.C.J. 2019, "Modeling and analysis of vibration energy harvesting system using piezo stack", International Journal of Mechanical and Production Engineering Research and Development, vol. 9, no. Special Issue 1, pp. 523-533.

[19] Sripada, A., Warrier, A., Kapoor, A., Gaur, H. \& Hemalatha, B. 2018, "Dynamic lateral balance of humanoid robots on unstable surfaces", International Conference on Electrical, Electronics, Communication Computer Technologies and Optimization Techniques, ICEECCOT 2017, pp. 539.

[20] Srinivasan, S., Thirumalaivasan, K. \& Sivakumaran, T.S. 2018 , "Performance evaluation of double-output luo converters", Journal of Advanced Research in Dynamical and Control Systems, vol. 10, no. 10 Special Issue, pp. 870-878.

[21] Karthikayen, A. \& Selvakumar Raja, S. 2018, "A skellam distribution inspired trust factor-based selfish node detection technique in MANETs", Journal of Advanced Research in Dynamical and Control Systems, vol. 10, no. 13, pp. 940-949.

\section{AUTHORS PROFILE}

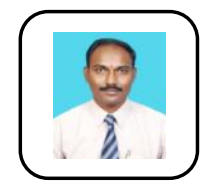

Dr.S.P.Vijayaragavan,Associate Professor,Department of EEE,Bharath Institute of Higher education and Research, Tamilnadu, India

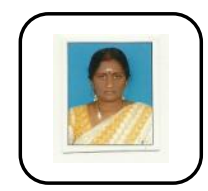

Dr.V.Jayalakshmi ,Associate Professor, Department of EEE, Bharath Institute of Higher education and Research, Tamilnadu, India



M.Krishna Kumar,Assistant Professor, Department of EEE, Bharath Institute of Higher education and Research, Tamilnadu, India 